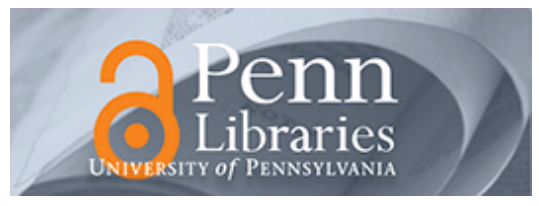

University of Pennsylvania

ScholarlyCommons

Accounting Papers

Wharton Faculty Research

2000

\title{
The Directors' and Officers' Insurance Premium: An Outside Assessment of the Quality of Corporate Governance
}

John E Core

University of Pennsylvania

Follow this and additional works at: https://repository.upenn.edu/accounting_papers

Part of the Accounting Commons, Business Administration, Management, and Operations Commons, and the Corporate Finance Commons

\section{Recommended Citation}

Core, J. (2000). The Directors' and Officers' Insurance Premium: An Outside Assessment of the Quality of Corporate Governance. The Journal of Law, Economics, \& Organization, 16 (2), 449-477. http://dx.doi.org/ 10.1093/jleo/16.2.449

This paper is posted at ScholarlyCommons. https://repository.upenn.edu/accounting_papers/93

For more information, please contact repository@pobox.upenn.edu. 


\title{
The Directors' and Officers' Insurance Premium: An Outside Assessment of the Quality of Corporate Governance
}

\author{
Abstract \\ Using a sample of directors' and officers' (D \& O) premiums gathered from the proxy statements of \\ Canadian companies, this article examines the D \& 0 premium as a measure of ex ante litigation risk. I \\ find a significant association between $D \& O$ premiums and variables that proxy for the quality of firms' \\ governance structures. The association between the proxies for governance structure quality and D \& 0 \\ premiums is robust to a number of alternative specifications. This article provides confirmatory evidence \\ that the $D \& O$ premium reflects the quality of the firm's corporate governance by showing that measures \\ of weak governance implied by the $D \& O$ premium are positively related to excess CEO compensation. \\ The overall results suggest that $D \& O$ premiums contain useful information about the quality of firms' \\ governance. \\ Disciplines \\ Accounting | Business Administration, Management, and Operations | Corporate Finance
}




\title{
The Directors' and Officers' Insurance Premium: An Outside Assessment of the Quality of Corporate Governance
}

\author{
John E. Core \\ The Wharton School \\ University of Pennsylvania \\ 2400 Steinberg Hall-Dietrich Hall \\ Philadelphia, PA 19104 \\ phone: 215-898-4821 \\ e-mail: jcore@wharton.upenn.edu
}

May 2000

This article is based on my dissertation at the University of Pennsylvania. I appreciate the guidance and comments of my dissertation committee, Stanley Baiman, David Cummins, Robert Holthausen, David Larcker (supervisor), and Madhav Rajan. This research has also benefited from the comments of Andrew Alford, Philip Berger, Robert Bowen, Alice Lee, Venky Nagar, Catherine Schrand, Alan Schwartz (the editor), D. Shores, Clifford Smith, Jr., René Stulz, Mark Zmijewski, three anonymous referees, and seminar participants at Harvard University, Massachusetts Institute of Technology, Stanford University, the University of California, Berkeley, the University of Chicago, the University of Michigan, the University of North Carolina, the University of Pennsylvania, the University of Rochester, the University of Washington, the 1996 Conference on Financial Economics and Accounting, and the 1999 Risk Theory Society.

I gratefully acknowledge financial assistance from the Ernst \& Young Foundation. The following people have generously shared their time and their firms' resources with me: William Dabaghi and John Hockenbury of Arter \& Hadden; Joseph Johnston, Jr. of Drinker, Biddle \& Reath; Mark Reszel of The ENCON Group; Ellen Glazerman and John Moyer of Ernst \& Young, LLP; Stephen Sills of Executive Risk Management Associates; William Brown of Marsh \& McClennan Inc; Robert Farquharson of Marsh \& McLennan Ltd; Pina de Santis of the Toronto Stock Exchange; and Ira Kay of the Wyatt Company. 


\title{
The Directors' and Officers' Insurance Premium: An Outside Assessment of the Quality of Corporate Governance
}

\author{
Using a sample of D\&O premiums gathered from the proxy statements of \\ Canadian companies, this article examines the D\&O premium as a measure of ex ante \\ litigation risk. I find a significant association between D\&O premiums and variables that \\ proxy for the quality of firms' governance structures. The association between the proxies \\ for governance structure quality and $\mathrm{D} \& \mathrm{O}$ premiums is robust to a number of alternative \\ specifications. This article provides confirmatory evidence that the D\&O premium \\ reflects the quality of the firm's corporate governance by showing that measures of weak \\ governance implied by the D\&O premium are positively related to excess CEO \\ compensation. The overall results suggest that D\&O premiums contain useful \\ information about the quality of firms' governance.
}




\section{Introduction}

Does corporate governance matter? Do shareholders sue more frequently when a firm has a weaker governance structure? Romano (1991) finds some evidence of an association between governance structure and ex post litigation risk. In this article, I use the directors' and officers' insurance (D\&O) premium as a measure of ex ante litigation risk, and examine whether there is detectable variation in the premium associated with proxies for the quality of firms' corporate governance.

D\&O insurance covers the monetary costs of lawsuits against directors and officers by shareholders or third-parties. The insurance provides coverage if the claim is settled with no admission of bad faith by a director or officer, or, if the suit is taken to trial, there is no finding of bad faith by the court. The D\&O insurer is an expert in assessing D\&O litigation risk, which is the probability the firm will be sued multiplied by the expected cost of a suit. The D\&O insurer sets a premium equal to its assessment of the firm's litigation risk plus a mark-up for its overhead and profit.

I hypothesize that the D\&O insurance premium reflects both business risk and the quality of the firm's governance structure. Consistent with most prior research, I characterize the quality of a firm's governance structure from the perspective of the outside shareholders: the governance structure is strong (weak) if it allows shareholders

to impose tight (loose) constraints on managers' actions. ${ }_{\text {I hypothesize that a firm with }}$ weaker governance has greater litigation risk because there is a greater chance that the managers will act against the interests of shareholders. Provided that the insurer cannot refuse to cover all claims related to weak governance, the insurance will be priced to 
reflect not only the firm's business risk but also the quality of the firm's governance structure.

My sample consists of a cross-section of publicly-traded Canadian firms with 1993 and 1994 fiscal year-ends. I select Canadian firms because they are required to disclose whether they purchased D\&O insurance and the details of the policies (Alboini, 1993). The corporate governance and legal systems in Canada are in general similar to those in the U.S. with two major differences. First, dual-class share structures continue to be common in Canada, and ownership is more concentrated (Rao and Lee-Sing, 1995). Second, during the sample period, the Canadian legal system was less conducive to "nuisance" suits over stock price declines, suits that often have no merit but are settled regularly (Alexander, 1991).

I find that $\mathrm{D} \& \mathrm{O}$ premiums are higher for firms with weaker governance structures. Variables that proxy for the quality of the governance structure are significant determinants of variation in the premium in regressions that include controls for business risk (such as firm size, financial performance, and U.S. exchange listing). The results indicate that $\mathrm{D} \& \mathrm{O}$ premiums are significantly higher when inside control of share votes is greater, when inside ownership is lower, when the board is comprised of fewer outside directors, when the $\mathrm{CEO}$ has appointed more of the outside directors, and when inside officers have employment contracts. In addition, consistent with Romano (1991), the results indicate that a disclosure of any type of pending or prior litigation significantly increases $\mathrm{D} \& \mathrm{O}$ premiums.

I validate the assessment of governance structure quality contained in the $\mathrm{D} \& \mathrm{O}$ 
premium by showing that excess CEO compensation is significantly higher for firms that have high $\mathrm{D} \& \mathrm{O}$ premiums relative to their business risk. This result provides confirmatory evidence that the $\mathrm{D} \& \mathrm{O}$ premium is higher when the insurer has determined that the firm's governance structure is weaker. The combination of this evidence with previous research that has linked excess CEO compensation to poor subsequent performance (Core, Holthausen, and Larcker, 1999) provides indirect evidence that the measure of weak governance contained in the D\&O premium captures features of firms' governance that make shareholders worse off. These results also suggest that the information contained in the $\mathrm{D} \& \mathrm{O}$ premium is a useful summary measure of the quality of a firm's governance.

The following section describes the institutional features of $\mathrm{D} \& \mathrm{O}$ insurance, and develops a hypothesis and econometric model for the $\mathrm{D} \& \mathrm{O}$ premium based on these features. Section 3 describes the data. Section 4 contains the empirical analysis of D\&O premiums, and Section 5 concludes.

\section{Governance structure quality and the $D \& O$ insurance premium}

\section{$2.1 \quad$ Hypothesis Development}

In both Canada and the U.S., roughly one-half of D\&O claims are brought by shareholders (the remainder by employees, customers, competitors, regulators, and other

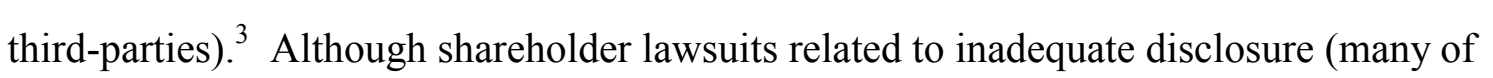
which are nuisance or "strike" suits by attorneys who specialize in filing suits following stock price drops) are the focus of much debate about D\&O lawsuits, these claims represent less than half of shareholder claims. Shareholders also sue when they believe 
D\&Os have not met their fiduciary duty. Examples of causes for these suits include acquisitions by the firm, bids by others to take over the firm, bankruptcy, executive compensation, and other self-interested transactions (Wyatt, 1993).

D\&O insurance covers the monetary costs of settling and defending these lawsuits. The insurance covers D\&Os provided that the claim did not result from their failure to act "honestly and in good faith," which means that the D\&Os did not violate their fiduciary duty to put the firm's interests ahead of their self-interest. For the purposes of determining whether a suit is covered by the insurance, D\&Os are assumed to have acted in good faith if the suit is settled out of court with no admission of bad faith, or, if the suit is taken to trial, there is no finding of bad faith. This bad faith exclusion in D\&O insurance gives officers and directors strong incentives to settle a suit without trial, because attorneys representing shareholders usually prefer to settle, and do not require an admission of bad faith as a condition of settlement. Likewise, a D\&O insurer settles many claims of questionable merit. The insurer settles these claims to avoid the potential that it could be required to pay damages above the policy limit if it refuses a good faith settlement offer (Alexander, 1991). Thus, although the insurer can successfully refuse to pay a claim for which there is incontrovertible evidence of management's failure to act in good faith, the insurer will settle a claim that arises from management opportunism that is apparent but too costly to verify.

The annual premium paid for a $\mathrm{D} \& \mathrm{O}$ policy covers claims made in the year of coverage up to the annual policy limit and subject to any deductible. A typical D\&O policy combines two types of insurance coverage: (1) corporate coverage, which 
reimburses the firm when it indemnifies D\&Os for the costs of a suit; and (2) personal coverage, which provides direct payments to D\&Os when the firm is not able or unwilling to indemnify them. 9 The personal and corporate coverage limits are typically the same. The corporate coverage portion carries a significant deductible (that averages approximately $2 \%$ of the limit), and the personal coverage portion carries a trivial deductible (usually zero). D\&O limits are stated on an annual basis for all covered losses during the policy year.

The D\&O insurance application process is structured to enable the insurer to obtain full information about the applicant's risk factors at a negligible cost. When a firm initially applies for D\&O insurance, it must submit an extensive written application which details the firm's past litigation experience, its past and future business activities, biographical data on its directors and officers, and its ownership structure (Holderness, 1990; Knepper and Bailey, 1993). On its annual renewal, the firm must state any change in its circumstances since its initial application. In addition to reviewing the application form, the D\&O insurer conducts background checks of the firm's management, and may also interview management. If the firm withholds any information relevant to its litigation risk, the insurer can use this omission to deny coverage in the event of a claim (Doyle, 1991). These features of the application process suggest that the insurer and the firm share similar beliefs about the firm's litigation risk at the time the insurance is priced. 6

The null hypothesis is that that the D\&O insurance premium reflects only the firm's business risk. My alternative hypothesis is that the premium also reflects the 
insurer's assessment of the quality of the firm's governance structure. A sufficient condition for the quality of corporate governance to be priced in the $\mathrm{D} \& \mathrm{O}$ premium is that the quality of governance structures varies in cross-section for otherwise identical firms and that it is too costly for the insurer to exclude all claims arising from weak corporate governance. ${ }^{\text {D }}$ As stated above, I characterize the quality of a firm's governance structure from the perspective of the outside shareholders: the governance structure is strong (weak) if it allows shareholders to impose tight (loose) constraints on managers' actions. A firm with weaker governance has greater litigation risk because the manager of such a firm is more likely to take an action which is subsequently revealed to be inconsistent with the shareholders' interests. Business risk (such as firm size, profitability, and relative exposure to the U.S. legal system) also increases litigation risk. Thus, a firm's D\&O premium is hypothesized to be a function of both the quality of its corporate governance and its business risk:

$$
\mathrm{D} \& \mathrm{O} \text { premium }=\mathrm{f}(\text { governance structure quality, business risk })
$$

\subsection{Econometric model}

This section develops an econometric model for the $\mathrm{D} \& \mathrm{O}$ premium based on institutional features of $\mathrm{D} \& \mathrm{O}$ insurance pricing and on the following two assumptions. First, consistent with the application process described above, I assume that the firm and insurer have symmetric beliefs about the probability and distribution of D\&O losses. Second, I assume that the D\&O insurance market is perfectly competitive, which is consistent with the market for $\mathrm{D} \& \mathrm{O}$ insurance during the sample period. ${ }^{\mathbb{Q}}$ In a competitive insurance market with symmetric information, any firm may purchase D\&O 
insurance and may choose the amount of limit it desires, and is charged a premium equal to its litigation risk plus a mark-up.

After the firm has completed the application process and has chosen a limit and deductible, the insurer sets a premium by adjusting the ratebook premium for that limit and deductible to reflect the difference in that firm's risk from the average risk. The firm's premium can be modeled as the product of the insurer's overhead-and-profit factor, the idiosyncratic litigation risk associated with this firm, and the ratebook conditional expected loss (which is a function of the limit and deductible). Because the premium is the product of these terms, the logarithm of the premium is linear in the firm's litigation risk, the conditional expected loss, and a constant:

$$
\begin{aligned}
& \log (\text { premium })=\beta_{0}+\beta_{1} \text { litigation risk }+ \\
& \beta_{3} \log (E[\text { ratebook loss } \mid \text { limit,deductible }])+\varepsilon_{1}
\end{aligned}
$$

Because the conditional expected loss, $\log (\mathrm{E}[$ ratebook loss $\mid$ limit,deductible $])$, is unobservable, I use the logarithm of the limit as a proxy:

$$
\log (\text { premium })=\beta_{0}+\beta_{1} \text { litigation risk }+\beta_{3} \log (\text { limit })+\varepsilon_{1}
$$

Based on the hypothesis above, a firm's litigation risk is a function of the quality of its corporate governance and its business risk:

$$
\begin{aligned}
\log (\text { premium })= & \beta_{0}+\beta_{1} \text { governance structure quality }+\beta_{2} \text { business risk }+ \\
& \beta_{3} \log (\text { limit })+\varepsilon_{1}
\end{aligned}
$$

Because higher risk firms have greater expected losses, they purchase greater limits (Wyatt, 1993; Core, 1997). Thus, the limit (and the conditional expected loss) is also a function of governance structure quality and business risk: 


$$
\log (\text { limit })=\gamma_{0}+\gamma_{1} \text { governance structure quality }+\gamma_{2} \text { business risk }+\varepsilon_{2}
$$

Note that $\log ($ premium $)$ does not enter equation (5). $\log ($ premium) reflects the average cost of coverage to the firm, and does not affect the firm's choice of the limit, which is a function of the marginal costs and benefits of coverage. ${ }^{-}$Substituting equation (5) into equation (4) yields the following reduced-form regression model for the D\&O premium:

$$
\log (\text { premium })=\delta_{0}+\delta_{1} \text { governance structure quality }+\delta_{2} \text { business risk }+\beta_{3} \varepsilon_{2}+\varepsilon_{1}
$$

where the total effect, $\delta_{\mathrm{i}}=\beta_{\mathrm{i}}+\beta_{3} \gamma_{\mathrm{i}}$, is the sum of the direct effect, $\beta_{\mathrm{i}}$, of the variable on $\log ($ premium $)$ and its indirect effect by increasing $\log ($ limit $), \beta_{3} \gamma_{\mathrm{i}}$.

Consistent estimates of this reduced-form model are obtained under the standard assumption that the governance structure and business risk variables are uncorrelated with $\varepsilon_{1}$ and $\varepsilon_{2}$. A necessary condition for this assumption to hold is that the governance structure and business risk variables are exogenous or predetermined at the time of the insurance pricing decision. This assumption is consistent with the assumption of symmetric information insurance contracting in which a firm can buy any limit it wishes, and it is charged a premium based on its loss probability and its conditional expected loss. 12

\section{The Data}

The initial sample consists of a cross-section of 246 firms with fiscal years ending between June 1, 1993 and May 31, $1994 .{ }^{13}$ From this initial sample, a sub-sample of 110 firms is used in the analysis of D\&O premiums, and a sub-sample of 208 firms is used in the confirmatory analysis using excess CEO compensation (described below in Section 
4.4). The sub-sample of 110 firms for the $\mathrm{D} \& \mathrm{O}$ premium analysis was obtained by eliminating 136 firms for the following reasons: (1) firm does not carry D\&O insurance (84 firms); (2) D\&O insurance is provided by firm's parent (23 firms); (3) premium data not disclosed or disclosed for only part of the D\&O coverage (26 firms); and (4) data missing for explanatory variables ( 3 firms). 14

I gather data on the logarithm of the $\mathrm{D} \& \mathrm{O}$ insurance premium and limit, and create proxy variables for governance structure quality and business risk. Data on the D\&O insurance policy and on the governance structure were gathered from the company's proxy statement. The next sub-section discusses nine characteristics of corporate governance that previous research has found to be related to variation in agency costs. The second sub-section develops a set of control variables for business risk. These variables were created using the company's annual report, the Canadian Compustat tapes, and stock price data obtained from the Toronto Stock Exchange. All independent variables used in the analysis of the D\&O premium are measured as of the end of the fiscal year prior to the proxy disclosure of the purchase of $\mathrm{D} \& \mathrm{O}$ insurance, under the assumption that the insurance was purchased at the beginning of the most recent fiscal year. Definitions of the variables, their predicted effect on the premium, and descriptive statistics are presented in Table 1. All dollar amounts reported in this article are denominated in Canadian dollars. 1.5

Place Table 1 Here

3.1 Proxies for governance structure quality

Firms with weaker governance are hypothesized to have higher D\&O premiums. 
To proxy for the quality of the firm's governance structure, I use three measures of ownership structure, three measures of board independence, and three measures of management entrenchment.

Prior research suggests that corporate governance is stronger when insiders own more stock and when there is monitoring by outside blockholders, and that corporate governance is weaker when insiders have greater voting control. Ownership of the firm's shares by its managers has countervailing effects: an incentive alignment effect that increases with the percentage of share value owned by the managers (Jensen and Meckling, 1976) and an entrenchment effect that increases with the percentage of share votes controlled by the manager (Morck, Shleifer, and Vishny, 1988; Stulz, 1988). Consistent with an entrenchment effect of share votes in dual-class firms, Eckbo and Verma (1994) find for a sample of Canadian firms that dividends decrease as inside voting control increases. Concentrated ownership of shares by outside shareholders increases the incentive to monitor and mitigates free-rider problems (Shleifer and Vishny, 1986).

I measure inside voting control (INS_VOTE) as the percentage of share votes controlled by inside directors, and inside ownership (INS_VALUE) as the percentage of

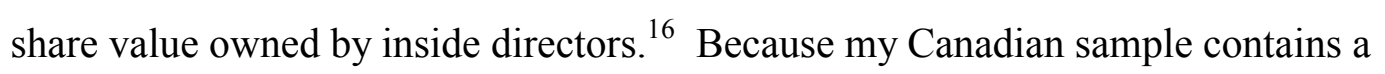
substantial proportion (approximately one-third) of firms with multiple classes of stock, the variables INS_VOTE and INS_VALUE are empirically distinct. I measure ownership by outside blockholders (OUT_BLOCK) with a dummy variable equal to one if an outside blockholder owns $10 \%$ of the firm, and zero otherwise. 
Corporate governance is expected to be stronger when the board is independent of the CEO (Jensen, 1993). Board independence is predicted to be positively related to the percentage of outside directors and negatively related to the percentage of outside directors appointed by the $\mathrm{CEO}$ and to whether the CEO is board chair. Dechow, Sloan, and Sweeney (1996) find that firms censured by the SEC for fraudulent reporting have fewer outside directors and are more likely to have a $\mathrm{CEO}$ who is also board chair. ${ }^{1.8}$ Prior research predicts and finds a negative relation between proxies for governance structure quality and the percentage of the outside directors appointed by the CEO (DIR_APP). Wade, O'Reilly and Chandratat (1990) document a positive association between DIR_APP and the adoption of golden parachutes, and Core, Holthausen, and Larcker (1999) document a positive association between DIR_APP and excess CEO compensation. The variable outside directors (DIR_OUT) is the number of outside directors as a percentage of total directors. ${ }^{1}$ DIR_APP is the percentage of outside directors who were appointed since the CEO joined the board. CEO_COB is a dummy variable equal to one if the $\mathrm{CEO}$ is also board chair, and zero otherwise.

Top executive employment contracts are expected to weaken governance by entrenching managers, but this entrenchment effect is expected to be lower when golden parachutes are attached to the contracts. Although the focus of their article is the efficient use of golden parachutes and employment contracts in protecting managers from takeover risk, Agrawal and Knoeber (1997) also find that CEO compensation is unconditionally higher at firms with these contracts, which is consistent with an entrenchment effect. Golden parachutes attached to employment contracts are expected to weaken this 
entrenchment effect by aligning managers' incentives so that they are less likely to resist takeovers (Lambert and Larcker, 1985). In addition to any entrenchment effects of employment contracts, the contracts themselves may be a source of litigation or may proxy for a business risk. Top executive employment contracts (CONTRACT) and golden parachutes (GOLD_PAR) are measured with dummy variables equal to one if top executives have employment contracts and golden parachutes, respectively, and zero otherwise.

The takeover market provides a mechanism for controlling agency problems (e.g., Fama and Jensen, 1983), so that takeover deterrents are expected to be associated with weaker governance. Consistent with takeover deterrents increasing entrenchment, Borokhovich, Brunarski, and Parrino (1997) find that firms that adopt anti-takeover charter amendments receive fewer takeover bids and pay higher CEO compensation. Nelson (1999) finds that firms underperform benchmark portfolios after they adopt poison pills and other takeover deterrents. In addition, the 1993 Wyatt survey reports that 3.5 percent of $\mathrm{D} \& \mathrm{O}$ claims are related to shareholder challenges to takeover defenses. The existence of takeover defenses may proxy for an increased likelihood of a takeover bid (Comment and Schwert, 1995) and an increased risk of litigation by shareholders seeking to remove the takeover deterrents. I measure takeover deterrents (TO_DETER) as a dummy variable equal to one if the firm has a poison pill, staggered board, or other takeover deterrents such as restrictions on ownership by non-Canadians, and zero otherwise.

\subsection{Proxies for business risk}


Firms with higher business risk are expected to have higher premiums, and six variables are employed as proxies for business risk.

As discussed in Knepper and Bailey (1993), D\&O insurers evaluate the quality of a firm's management, and firms with higher quality management are hypothesized to have lower litigation risk. The logarithm of the number of years that the $\mathrm{CEO}$ has been on the board of directors is used as a proxy for management quality (CEO_EXP) $\stackrel{\text { [0 }}{\text { Provided }}$ that the governance structure variables control for any entrenchment effects that hinder the removal of a low-quality CEO, the coefficient on CEO_EXP will measure the benefits of having an experienced $\mathrm{CEO}$, net of any costs of entrenchment. In addition, low CEO_EXP (because of recent CEO turnover) may also serve as a proxy for poor past company performance, which is also expected to increase litigation risk.

D\&O claims often arise because of poor financial performance (Wyatt, 1993). The firm's return on equity (ROE) is used as a proxy for financial performance and is expected to be negatively related to the $\mathrm{D} \& \mathrm{O}$ premium. Larger firms are expected to have higher litigation risk. The 1993 Wyatt survey indicates that a U.S. company with over $\$ 1$ billion in assets is over ten times more likely be sued than a company with under $\$ 100$ million in assets. I measure firm size (SIZE) with the logarithm of total assets.

Companies that have disclosed pending or prior litigation (PRIOR_LIT) are expected to have higher $\mathrm{D} \& \mathrm{O}$ premiums because this litigation may lead to a $\mathrm{D} \& \mathrm{O}$ claim or because of a negative reputational effect (Romano, 1991). Because of the differences in the Canadian legal system discussed above, Canadian D\&O awards are expected to be less substantial than U.S. awards. Firms with U.S. operations (US_OPS) or a U.S. 
exchange listing (US_EXCH) are predicted to have greater litigation risk.

\section{Empirical analysis of the D\&O premium}

\section{$4.1 \quad$ Results}

The association between the level of the D\&O premium, governance structure quality, and business risk is examined using the reduced-form equation (6) developed above in Section 2.2. This regression equation includes as dependent variable $\log ($ premium $)$ and as independent variables the proxies for governance structure quality and business risk defined in Table 1. Also included as an independent variable is $\varepsilon_{2}$, which is the error term from equation (5), which expresses $\log (\operatorname{limit})$ as a function of governance structure quality and business risk. To estimate equation (6), I conduct a first-stage regression of $\log ($ limit $)$ on the proxies for governance structure quality and business risk to obtain $\hat{\varepsilon}_{2}$, the residual of $\log ($ limit). I then estimate the following second-stage regression:

$$
\begin{aligned}
\log (\text { premium })= & \delta_{0}+\delta_{1} \text { governance structure quality }+\delta_{2} \text { business risk }+ \\
& \beta_{3} \text { residual of } \log (\text { limit })+\varepsilon_{1}
\end{aligned}
$$

The residual of $\log ($ limit) controls for information in $\log ($ limit $)$ that is orthogonal to the

other regressors. ${ }^{\square}$ As discussed above, the estimated coefficients $\hat{\delta}_{i}$ capture the total effects of the proxies for governance structure quality and business risk on the D\&O premium. 22

The regression model in Panel 1 of Table 2 shows that the governance structure variables add significant explanatory power to the model for $\log ($ premium). The model has significant explanatory power (adjusted $\mathrm{R}^{2}=76.3 \%$ ), and all of the governance 
structure variables and business risk variables have the predicted signs. Five of the nine governance structure variables are significant. A partial F-test $(p$-value $=0.05)$ rejects the hypothesis that the coefficients on all of the governance structure variables are equal to zero, which means that the variables add a significant amount of explanatory power to the model for $\log$ (premium). The combined evidence on the governance structure variables - their coefficients have the predicted signs, five of the variables are individually significant, and the variables are collectively significant -- is consistent with the hypothesis that the D\&O premium reflects the quality of the firm's governance structure.

The positive and significant coefficient on INS_VOTE is consistent with an entrenchment effect from insider voting control, and the negative and significant coefficient on INS_VALUE is consistent with an incentive alignment effect that increases as insiders hold more of the value of the firm. This result complements research by Morck, Shleifer, and Vishny (1988) and Stulz (1988) by highlighting the importance of the dual role of stock ownership in entrenching and motivating managers. The insignificant coefficient on OUT_BLOCK is consistent with offsetting effects of outside shareholders: they simultaneously increase governance structure quality and litigation risk because they use lawsuits as a substitute monitoring device (Romano, 1991). ${ }^{23}$ The coefficient on DIR_OUT is negative, consistent with monitoring benefits of outside directors. The coefficient on DIR__APP is positive, consistent with governance being weaker when outside directors are less independent. The coefficient on CONTRACT is 
positive, consistent with the hypothesis that governance structure quality decreases when managers entrench themselves by obtaining employment contracts.

All of the business risk variables are significant. CEO_EXP has a negative coefficient, consistent with the hypothesis that firms with more experienced management are more stable and less risky, after controlling for any entrenchment effects associated with a CEO of long tenure. ROE has a negative coefficient, indicating that firms with better operating performance have lower litigation risk. The significant positive coefficients on SIZE, PRIOR_LIT, US_OPS, and US_EXCH are consistent with my hypotheses and with economic intuition. Larger firms are more likely to be the subject of litigation, and U.S. operations or a U.S. exchange listing exposes the firm to the more costly U.S. litigation environment. The positive coefficient on PRIOR_LIT is consistent with the findings of Romano (1991), and with the non-mutually exclusive explanations that $\mathrm{D} \& \mathrm{O}$ insurers are concerned about the spillover effects of pending litigation, that prior litigation has a negative reputational effect, or that prior litigation may itself be a manifestation of weak governance.

Finally, the coefficient on the variable residual of $\log (\operatorname{limit})$ is significant and positive, which indicates that information in the limit that is orthogonal to the governance structure and business risk variables is significantly associated with $\log ($ premium $) .24$ Recall that not all firms choose to purchase insurance, and that 26 firms that purchased insurance had missing premium data (as described in Section 3). Does the choice to purchase insurance introduce a sample selection bias into the results? To test for a selection bias, I use the econometric methods developed by Heckman (1979). I 
estimate a probit model for the choice to purchase insurance using all firms, and a second-stage OLS regression for $\log$ (premium) which includes a variable (the inverse Mills ratio) that corrects for the fact that purchase is predictable. The coefficient on the inverse Mills ratio in the OLS model for the premium is insignificant, and provides no evidence consistent with sample-selection bias. Does the missing premium data on 26 firms introduce a selection bias into the results? I estimate a probit model in which the 26 firms with missing data are coded zero, and the 110 firms with full data are coded one. The probit model indicates that there is no predictable difference between the two sets of firms (a likelihood ratio test is unable to reject the hypothesis that the coefficients on all of the governance structure and business risk proxies are zero). Because the two sets of firms are not predictably different, there is by definition no sample selection bias.

To ensure that the results are not driven by outliers, I re-estimate the regression coefficients using a two-stage weighted least squares procedure developed by Welsch (1980), which is an efficient way of minimizing the influence of outliers without entirely discarding the information that they contain. The qualitative results are unchanged: the signs of the coefficient estimates remain the same, the same variables are significant, and the governance structure variables continue to explain a significant amount of the variation in the premium.

\subsection{Sensitivity tests}

The remaining panels of Table 2 present the results of sensitivity tests of the main model presented in Panel 1. I perform a number of additional tests to ensure that inference is robust to the potential that the significant positive coefficient on 
CONTRACT reflects a business risk (such as the potential for litigation over the contracts) instead of, or in addition to, measuring entrenchment and weak governance. First, when I classify CONTRACT and GOLD_PAR as business risk variables, the restriction that the coefficients on the seven remaining governance structure variables are equal to zero is consistently rejected, as shown by the significant partial F-tests presented at the bottom of the Table 2. Second, in Panel 2 of Table 2, I present a model in which CONTRACT and GOLD_PAR are omitted from the regression. Again, a partial F-test (p-value $<0.10$ ) rejects the restriction that the coefficients on the seven remaining governance structure variables are equal to zero. Finally, the confirmatory analysis using CEO compensation described below in Section 4.4 yields the same inference whether or not CONTRACT and GOLD_PAR are included as measures of governance quality. I perform a number of sensitivity tests to ensure that omitted variables are not inducing spurious inference with respect to the governance structure variables. First, in Panel 3, I include the logarithm of the corporate deductible as an additional regressor. Although the inclusion of the variable tends to reduce the magnitudes of the coefficient estimates (particularly on SIZE, US_OPS, and US_EXCH), inference on the governance structure variables is unaffected. In results not presented in Table $2, \log$ (market value of equity) is introduced as an additional proxy for business risk. The variable is highly correlated with SIZE and increases multicollinearity problems in the regression without improving explanatory power, and its coefficient is not significant. The governance structure variables continue to be jointly significant in explaining $\log ($ premium). Similarly, if variables measuring leverage, stock return, stock volatility, and growth 
opportunities are included either separately or together in the regression, the variables are not significant, the governance structure variables are collectively significant, and the coefficient estimates on the other independent variables are similar to those in Panel 1.

In Panel 4, I include stock volatility and five indicators for high-risk industries.

Prior research (e.g., Alexander, 1991; Jones and Weingram, 1998; Wyatt, 1993) provides evidence that both stock volatility and industry membership are associated with shareholder suits. This prior research and an interview with a D\&O underwriter suggest that the following five industries were expected to have higher litigation risk in Canada and the U.S. during the sample period: technology, media, banking, other financial institutions, and real estate. While STOCK VOLATILITY is not significant when included by itself, it is marginally significant when the high-risk industry indicators are included. However, an F-test $(\mathrm{p}$-value $=0.19)$ does not reject the restriction that the coefficients on stock volatility and the five industry indicators are all zero. As shown in the Panel 4, the inclusion of these variables has no effect on inference with respect to the governance structure variables.

Panel 5 of Table 2 indicates that the results are robust to the inclusion of twelve industry dummy variables (the five-high risk industries plus dummy variables for the remaining major industry groups). The industry effects add no explanatory power to the model. The governance structure variables continue to be jointly significant in explaining $\log$ (premium), although the coefficients on INS_VALUE and DIR_OUT lose significance. 
Finally, I perform sensitivity tests related to the inclusion of the multiple class firms in the sample. Because various elements of a firm's governance structure substitute for one another, one would expect that the governance structures of multiple class firms differ from those of single class firms. However, the data no not support the hypothesis that the governance structure variables of multiple class firms have different effects on the premium than those of single class firms. ${ }^{27}$ As a second test, I substitute a single variable measuring the net of insider percentage voting control over insider percentage share-ownership for its two components. The coefficient on this net voting control variable is positive and significant, and the significance levels on the remaining variables are unaffected. This result provides evidence that the coefficients on INS_VOTE and INS_VALUE are in fact capturing the net agency costs of insider control of share votes and insider ownership of share value, and are not merely an artifact of the high correlation between the two variables. Finally, although the multiple class firms do not differ significantly in size from the single class firms, there are certain industries in which multiple class firms are relatively common or uncommon. When industry indicators for these industries are included in the model in Panel 1, inference on INS_VOTE and INS_VALUE and the remaining governance variables is unchanged.

\subsection{Direct and indirect effects of governance structure quality}

I define the variable GOVERNANCE QUALITY as the sum of the governance structure variables weighted by their estimated coefficients $\hat{\delta}_{i}$ shown in Panel 1 of Table 2, multiplied by negative one: 


\section{GOVERNANCE QUALITY $\equiv$}

$-\left(\hat{\delta}_{1}\right.$ inside voting control $+\ldots+\hat{\delta}_{9}$ takeover deterrents $)$

This variable is standardized to mean zero and unit variance. Panel 1 of Table 3

illustrates OLS regression results for equation (7) when this variable is substituted for the nine variables that compose it in a model for the logarithm of the $\mathrm{D} \& \mathrm{O}$ premium. The coefficient of -0.275 on the standardized variable GOVERNANCE QUALITY indicates that a firm with corporate governance one standard deviation weaker than average pays a D\&O premium roughly 32 percent more than an otherwise similar firm.

\section{Place Table 3 Here}

The reduced-form equation (7) estimated in Panel 1 captures the total effect of GOVERNANCE QUALITY and the business risk variables on $\log$ (premium). For example, the estimated - 0.275 total effect of GOVERNANCE QUALITY on $\log$ (premium) shown in Panel 1 consists of the sum of its direct effect on $\log$ (premium) shown in Panel $2(-0.210)$ and its indirect effect on $\log ($ premium) through its effect on $\log ($ limit $)$ shown in Panel $3\left(0.388^{*}-0.167=-0.065\right)$. The regression coefficients in Panel 2 show the direct effect of a variable on $\log$ (premium) in excess of that variable's indirect effect through $\log ($ limit). The significant coefficient on GOVERNANCE QUALITY in Panel 2 indicates that weaker governance is associated with significantly higher premiums even after controlling for the indirect effect that weaker governance has on increasing the limits shown in Panel 3.28

\subsection{Confirmatory analysis using excess CEO compensation}


The preceding tests indicate that proxies for governance structure quality add significant explanatory power to regression models for the D\&O premium. These results suggest that these proxies for governance structure quality are associated with increased litigation risk, but do not demonstrate that weaker governance structures are worse for shareholders. In this section, I provide confirmatory evidence that D\&O premiums reflect the quality of firms' governance structures by demonstrating that measures of weak governance implied by the $\mathrm{D} \& \mathrm{O}$ premium have a statistically positive relation with excess CEO compensation.

Recent research finds that CEO compensation in excess of its standard economic determinants is a proxy for weak corporate governance that makes shareholders worse off (e.g., Borokovich, Brunarski, and Parrino, 1997; Hallock, 1997; and Core, Holthausen and Larcker, 1999). If the measure of weak governance implied by the D\&O premium is positively associated with excess CEO compensation, then this result suggests that the increase in the $\mathrm{D} \& \mathrm{O}$ premium results from an assessment of weaker governance that makes shareholders worse off (and is not simply an assessment of increased litigation risk associated with governance structures that allow more managerial discretion).

As a first test of this hypothesis, I specify a linear regression model for the logarithm of CEO total compensation that includes GOVERNANCE QUALITY (as defined by equation (8)) and control variables. The control variables for the economic determinants of CEO pay are: (1) SIZE; (2) the market-to-book assets ratio as a proxy for the firm's growth opportunities; (3) firm performance (stock return and ROE); and (4) the expected difference in CEO compensation for CEOs more exposed to the U.S. labor 
market (US_OPS and US_EXCH). 29 This empirical model for CEO compensation is similar to extensions of the Smith and Watts (1992) demand-side model for CEO compensation employed by Agrawal and Knoeber (1997) and Core, Holthausen, and Larcker (1999).

The sample used is 208 firms with CEO compensation data obtained by deleting 30 firms with missing compensation data and 8 firms with missing independent variables from the initial sample of 246 firms described above. ${ }^{30}$ Total CEO compensation is the sum of base salary, annual incentive payments, the value of option grants and grants under long-term incentive plans, and the value of any benefits and perquisites. 3 This data is gathered from the proxy statement. Table 4 contains definitions and descriptive statistics for the variables.

Place Table 4 Here

GOVERNANCE QUALITY in Model 1 of Table 5 has a highly significant negative coefficient, and indicates that excess pay is higher when governance is weaker. This result provides evidence that the governance structure variables underlying GOVERNANCE QUALITY in fact proxy for the quality of the firm's governance structure. The coefficient on the standardized variable GOVERNANCE QUALITY indicates that a CEO at a firm with corporate governance one standard deviation weaker than average earns roughly 26 percent more than the CEO of an otherwise similar firm. With the exception of US_OPS, the coefficients on the control variables have the predicted signs and are consistent with the findings of prior research (e.g., Smith and 
Watts, 1992) on the association between firm size, growth opportunities, performance and CEO compensation.

\section{Place Table 5 Here}

The regression model in Panel 2 of Table 5 includes the interactive variable (GOVERNANCE QUALITY) X (firm has insurance), which is equal to GOVERNANCE QUALITY if the firm has D\&O insurance, and zero otherwise. The coefficient on this interactive variable is insignificant while the coefficient on GOVERNANCE QUALITY remains negative and significant. This evidence is not consistent with GOVERNANCE QUALITY proxying for some risk for which CEOs must receive higher compensation. If GOVERNANCE QUALITY were a risk factor in CEO compensation, one would expect that CEOs with D\&O insurance would receive lower compensation for the risk, i.e., that the coefficient on the interactive variable would be positive and significant. Instead, the insignificant coefficient on the interactive term provides additional evidence that the governance structure variables underlying GOVERNANCE QUALITY proxy for the quality of the firm's governance structure.

As a more direct test of the hypothesis that D\&O premiums reflect weak governance, I use as a proxy for weak governance the residual premium unexplained by the business risk variables and $\log ($ limit). PREMIUM RESIDUAL is obtained by excluding all of the governance structure variables in the estimation of equation (7) for $\log$ (premium), and is equivalent to the following regression: $\frac{33}{3}$ 


$$
\log (\text { premium })=\beta_{0}+\beta_{2} \text { business risk }+\beta_{3} \log (\text { limit })+\varepsilon_{3}
$$

Because the governance structure proxy variables are omitted from the regression, PREMIUM RESIDUAL captures any amount of the premium that is related to the firm's governance structure. PREMIUM RESIDUAL can be computed for all of the 110 firms with D\&O premiums, but only 97 of these firms have data available for the analysis of CEO compensation. PREMIUM RESIDUAL has a significant positive correlation (0.34) with GOVERNANCE QUALITY. The final panel of Table 5 illustrates that PREMIUM RESIDUAL has a significant positive association with excess CEO pay, and provides additional confirmatory evidence that the $\mathrm{D} \& \mathrm{O}$ premium is higher when governance is weaker.

\section{Conclusion}

Using a sample of $D \& O$ premiums gathered from the proxy statements of Canadian companies, this article documents that there is detectable variation in D\&O premiums that is related to variables that proxy for the quality of firms' governance. The association between these variables and higher $\mathrm{D} \& \mathrm{O}$ premiums is robust to a number of alternative specifications. I provide confirmatory evidence that the D\&O premium reflects the quality of the firm's corporate governance by showing that measures of weak governance implied by the $\mathrm{D} \& \mathrm{O}$ premium are positively related to excess CEO compensation. Combined with the findings of previous research that has found an association between weak governance and excess CEO compensation, this finding provides indirect evidence that $\mathrm{D} \& \mathrm{O}$ insurers charge higher premiums when firms have governance structures that make shareholders worse off. 
There is growing consensus inside and outside academics that weak governance is costly to outside shareholders. However, it is difficult and costly for shareholders to assess the quality of firms' governance. As a result, in the United States, institutional shareholders buy ratings of firms' corporate governance from outside specialists such as Institutional Shareholder Services (ISS). ISS relies on publicly-available data, and has no comparative advantage in creating its ratings other than its data processing capabilities. The results in this article indicate that another outsider, the $\mathrm{D} \& \mathrm{O}$ insurer, is already making this assessment, and is in fact being provided non-public data by firms to make this assessment. Excess D\&O premiums contain information about the quality of firms' governance. Unlike the Ontario Securities Commission, the U.S. Securities and Exchange Commission does not require that U.S. firms disclose anything about their D\&O insurance to their shareholders. The direct evidence in this article suggests that U.S. shareholders would find the independent assessment contained in these premiums to be a useful summary of the likelihood of litigation associated with firms' governance structures. The indirect evidence in this article suggests that this piece of summary information would also provide an additional tool for assessing the relative effectiveness of firms' governance structures in maximizing returns to outside shareholders. 


\section{References}

Agrawal, Anup and Charles R. Knoeber. 1997. "Managerial Compensation and the Threat of Takeover," 47 Journal of Financial Economics 219-239.

Alboini, Victor P. 1993. Securities Law and Practice, Release No. 5. Toronto, Canada: Carswell.

Alexander, Janet Cooper. 1991. "Do the Merits Matter? A Study of Settlements in Securities Class Actions," 43 Stanford Law Review 497-598.

Baillie, James C. 1996. "Comments of a Business Lawyer on Rules Governing Boards of Canadian Corporations," 28 Canadian Business Law Journal 127-139.

Beauschesne, Eric. 1994. "U.S. CEOs Earn Double Wages of Canadian Counterparts," The Ottawa Citizen C3 (Jan. 18).

Belsley, David A., Edwin Kuh, and Roy E. Welsch. 1980. Regression Diagnostics: Identifying Influential Data and Sources of Collinearity. New York: John Wiley \& Sons.

Borokhovich, Kenneth A., Kelly R. Brunarski, and Robert Parrino. 1997. "CEO Contracting and Antitakeover Amendments," 52 Journal of Finance 1495-1517.

Brickley, James A., Jeffrey L. Coles, and Gregg Jarrell. 1997. "Leadership structure: Separating the CEO and Chairman of the Board," 3 Journal Of Corporate Finance 189-220.

Clarkson, Peter M., and Dan A. Simunic. 1994. "The Association between Audit Quality, Retained Ownership, and Firm-Specific Risk in U.S. vs. Canadian IPO markets," 17 Journal of Accounting and Economics 207-228.

Comment, Robert, and G. William Schwert. 1995. "Poison or placebo? Evidence on the Deterrence and Wealth Effects of Modern Antitakeover Measures," 39 Journal of Financial Economics 3-43.

Core, John E. 1997. "On the Corporate Demand for Directors' and Officers' Insurance," 64 The Journal of Risk and Insurance 63-87.

, Robert W. Holthausen, and David F. Larcker. 1999. "Corporate Governance, Chief Executive Officer Compensation, and Firm Performance," 51 Journal of Financial Economics 371-406. 
Cox, John C., Stephen A. Ross, and Mark Rubinstein. 1979. "Option Pricing: A Simplified Approach," 7 Journal of Financial Economics 229-63.

Cummins, J. D. 1991. "Statistical and Financial Models of Insurance Pricing and the Insurance Firm," 58 Journal of Risk and Insurance 261-302.

D'Arcy, Stephen P. et al. 1990. Foundations of Casualty Actuarial Science. Arlington, VA: Casualty Actuarial Society.

Daniels, Ronald J. and Susan M., Hutton. 1993. "The Capricious Cushion: The Implications of the Directors' and Officers' Insurance Liability Crisis on Canadian Corporate Governance," 22 Canadian Business Law Journal 182-230.

Dechow, Patricia M., Richard G. Sloan, and Amy P. Sweeney. 1996. "Causes and Consequences of Earnings Manipulations : An Analysis of Firms Subject to Enforcement Actions by the SEC," 13 Contemporary Accounting Research 1-36.

Demsetz, Harold. 1983. "The Structure of Ownership and the Theory of the Firm," 26 Journal of Law and Economics 375-393.

Doyle, Corbette S. 1991. "Bargaining on D\&O Coverage," The Corporate Board Special Report 13-17 (July/August).

Eckbo, B. Epsen and Savita Verma. 1994. "Managerial Ownership, Voting Power and Cash Dividend Policy," 1 Journal of Corporate Finance 33-62.

Fama, Eugene F., and Michael C. Jensen. 1983. "Separation of Ownership and Control," 26 Journal of Law and Economics 301-325.

Hallock, Kevin F. 1997. "Reciprocally Interlocking Boards of Directors and Executive Compensation," 32 Journal of Financial and Quantitative Analysis 331-344.

Heckman, James. 1979. "Sample Selection Bias as a Specification Error," 47 Econometrica 153-61.

Holderness, Clifford G. 1990. "Liability Insurers as Corporate Monitors," 10 International

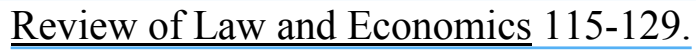

Jensen, Michael C. 1993. "The Modern Industrial Revolution, Exit, and the Failure of Internal Control Systems," 48 Journal of Finance 831-880. 
and William Meckling. 1976. "Theory of the Firm: Managerial Behavior, Agency Costs and Ownership Structure," 3 Journal of Financial Economics 305-360.

Jones, Christopher L. and Seth E. Weingram. 1998. "Why 10b-5 Litigation Risk is Higher for Technology and Financial Services Firms," Working paper, George Washington University.

Knepper, William E. and Dan A. Bailey. 1993. Liability of Corporate Officers and Directors. Charlottesville, VA: The Michie Company.

La Porta, Rafael, Florencio Lopes-de-Silanes, Andrei Shleifer, and Robert W. Vishny. 1997. "Legal Determinants of External Finance," 52 Journal of Finance 11311150.

Lambert, Richard A. and David Larcker. 1985. "Golden Parachutes, Executive DecisionMaking and Shareholder Wealth," 7 Journal of Accounting and Economics 179203.

Morck, Randall, Andrei Shleifer, and Robert W. Vishny. 1988. "Management Ownership and Market Valuation: An Empirical Analysis," 20 Journal of Financial Economics 293-315.

Nelson, James 1999. "Corporate Governance Practices and Firm Performance: An Examination of an Endogenous Relationship," Working paper, University of Arizona.

Parry, Mark E. and Arthur E. Parry. 1991. "The Purchase of Insurance by a Risk-Neutral Firm for a Risk-Averse Agent," 58 Journal of Risk and Insurance 31-46.

Rao, S. R. and C.R. Lee-Sing. 1995. "Governance Structure, Corporate Decision-Making and Firm Performance in North America," in R. J. Daniels and R. Morck, eds., Corporate Decision-Making in Canada. Calgary, Canada: University of Calgary Press.

Romano, Roberta. 1991. "The Shareholder Suit: Litigation without Foundation?" 7 The Journal of Law, Economics, \& Organization 55-87.

Rousseau, Stephane. 1997. "Review of Corporate Decision-Making in Canada, ed. Daniels, R. J., Morck, R. (University of Calgary Press, 1995)," 28 Canadian Business Law Journal 310-320.

Rowley, J. William. 1996. "Toronto Stock Exchange Seeks Improved Disclosure," 52 International Financial Law Review 45-47 (May). 
Shleifer, Andrei, and Robert W. Vishny. 1997. "A Survey of Corporate Governance," 52 Journal of Finance 737-783. and Robert W. Vishny. 1986. "Large Shareholders and Corporate Control," 94 Journal of Political Economy 461-488.

Smith, Clifford W., and Ross L. Watts. 1992. "The Investment Opportunity Set and Corporate Financing, Dividend, and Compensation Policies," 32 Journal of Financial Economics 263-92.

Stulz, Rene M. 1988. "Managerial Control of Voting Rights: Financing Policies and the Market for Corporate Control," 20 Journal of Financial Economics 25-45.

Trebilcock, Michael J. 1987. "The Social Insurance-Deterrence Dilemma of Modern American Tort Law: A Canadian Perspective on the Liability Insurance Crisis," 24 San Diego Law Review 929-1002.

Wade, James, Charles A. O'Reilly, and Ike Chandratat. 1990. "Golden Parachutes: CEOs and the Exercise of Social Influence," 35 Administrative Science Quarterly 587603.

Weisbach, Michael S. 1988. "Outside Directors and CEO Turnover," 20 Journal of Financial Economics 421-60.

Welsch, Roy E. 1980. "Regression Sensitivity Analysis and Bounded-Influence Estimation," in J. Kmenta and J. B. Ramsay, eds., Evaluation of Econometric Models. New York: Academic Press.

The Wyatt Company. 1993. Directors and Officers Liability Survey. Chicago, IL: Wyatt Company.

Zingales, Luigi. 1998. "Corporate Governance," in P. Newman, ed., The New Palgrave Dictionary Of Economics And The Law. New York: Stockton Press. 
Table 1. Descriptive Statistics for the D\&O Premium and its Hypothesized Determinants

The sample consists of 110 observations. All variables are measured at the end of the fiscal year or for the fiscal year ending prior to the year of purchase of D\&O insurance. Dollar amounts are in Canadian dollars.

D\&O Insurance Variables

\begin{tabular}{|c|c|c|c|c|c|}
\hline Variable & Variable Definition & $\begin{array}{l}\text { Predicted } \\
\text { Sign }\end{array}$ & Mean & Median & Std Dev. \\
\hline D\&O premium & $\begin{array}{l}\text { Dollar amount of the annual D\&O } \\
\text { insurance premium }\end{array}$ & & 167,780 & 103,477 & 188,223 \\
\hline Log(premium) & $\begin{array}{l}\text { Logarithm of the premium for } \mathrm{D} \& \mathrm{O} \\
\text { insurance }\end{array}$ & & 11.556 & 11.547 & 0.966 \\
\hline D\&O limit & Annual coverage limit & & $26,431,545$ & $20,000,000$ & $24,548,990$ \\
\hline $\log ($ limit $)$ & Logarithm of the limit for D\&O insurance & + & 16.788 & 16.811 & 0.765 \\
\hline
\end{tabular}

Governance Structure Variables

\begin{tabular}{|c|c|c|c|c|c|}
\hline Variable & Variable Definition & $\begin{array}{l}\text { Predicted } \\
\text { Sign }\end{array}$ & Mean & Median & Std Dev. \\
\hline$\overline{\text { INS_VOTE }}$ & $\begin{array}{l}\text { Percentage of share votes controlled by } \\
\text { inside directors }\end{array}$ & + & $17.1 \%$ & $0.1 \%$ & $28.4 \%$ \\
\hline INS_VALUE & $\begin{array}{l}\text { Percentage of share value owned by inside } \\
\text { directors }\end{array}$ & - & $8.1 \%$ & $0.1 \%$ & $14.4 \%$ \\
\hline OUT_BLOCK & $\begin{array}{l}=1 \text { when an outside blockholder owns over } \\
10 \% \text { of the stock }\end{array}$ & - & 0.555 & 1.000 & 0.499 \\
\hline DIR_OUT & $\begin{array}{l}\text { Number of outside directors as a percentage } \\
\text { of the total number of directors }\end{array}$ & - & $71.0 \%$ & $77.4 \%$ & $18.9 \%$ \\
\hline DIR_APP & $\begin{array}{l}\text { Percentage of outside directors who were } \\
\text { appointed since the CEO joined the board }\end{array}$ & + & $63.3 \%$ & $73.9 \%$ & $36.7 \%$ \\
\hline CEO_COB & $=1$ if the $\mathrm{CEO}$ is also board chair & + & 0.536 & 1.000 & 0.501 \\
\hline CONTRACT & $\begin{array}{l}=1 \text { if the CEO or any other top executive } \\
\text { has employment contract }\end{array}$ & + & 0.518 & 1.000 & 0.502 \\
\hline GOLD_PAR & $\begin{array}{l}=1 \text { if the } \mathrm{CEO} \text { or any other top executive } \\
\text { has a golden parachute }\end{array}$ & - & 0.282 & 0.000 & 0.452 \\
\hline TO_DETER & $\begin{array}{l}=1 \text { if the firm has a staggered board, poison } \\
\text { pill, or any other takeover restrictions }\end{array}$ & + & 0.255 & 0.000 & 0.438 \\
\hline \multicolumn{6}{|c|}{ Business Risk Variables } \\
\hline Variable & Variable Definition & $\begin{array}{l}\text { redicted } \\
\text { Sign }\end{array}$ & Mean & Median & Std Dev. \\
\hline CEO_EXP & $\begin{array}{l}\text { Logarithm of the number of years the CEO } \\
\text { has served on the board of directors }\end{array}$ & - & 1.925 & 2.013 & 0.993 \\
\hline ROE & $\begin{array}{l}\text { net income before extraordinary items } \\
\text { divided by ending equity }\end{array}$ & - & $-2.9 \%$ & $2.9 \%$ & $23.6 \%$ \\
\hline SIZE & logarithm of total assets & + & 20.603 & 20.515 & 1.698 \\
\hline PRIOR_LIT & $\begin{array}{l}=1 \text { if the firm disclosed pending or prior } \\
\text { litigation in either its annual report or proxy }\end{array}$ & + & 0.536 & 1.000 & 0.501 \\
\hline US_OPS & $=1$ if the firm has sales or assets in the U.S. & + & 0.727 & 1.000 & 0.447 \\
\hline US_EXCH & $=1$ if the firm is listed on a U.S. exchange & + & 0.327 & 0.000 & 0.471 \\
\hline
\end{tabular}


Table 2. Regressions of the logarithm of the D\&O premium

The sample consists of 110 observations. The residual of $\log ($ limit $)$ is the residual from a regression of $\log (\operatorname{limit})$ on the governance structure quality and business risk variables. All other variables are defined in Table 1. T-statistics (based on OLS standard errors) appear in parentheses below each coefficient estimate.

\begin{tabular}{|c|c|c|c|c|c|c|}
\hline $\begin{array}{c}\text { Independent } \\
\text { Variable }\end{array}$ & $\begin{array}{c}\text { Predicted } \\
\text { Sign }\end{array}$ & (1) & (2) & (3) & (4) & (5) \\
\hline$\overline{\text { INS_VOTE }}$ & + & $\begin{array}{l}0.646^{* *} \\
(2.18)\end{array}$ & $\begin{array}{l}0.602 * * \\
(2.01)\end{array}$ & $\begin{array}{l}0.571^{*} \\
(1.98)\end{array}$ & $\begin{array}{l}0.598^{*} \\
(1.98)\end{array}$ & $\begin{array}{l}0.603 * \\
(1.93)\end{array}$ \\
\hline INS_VALUE & - & $\begin{array}{l}-0.958^{*} \\
(-1.79)\end{array}$ & $\begin{array}{l}-0.988^{*} \\
(-1.81)\end{array}$ & $\begin{array}{l}-0.906^{*} \\
(-1.74)\end{array}$ & $\begin{array}{l}-0.950 * \\
(-1.72)\end{array}$ & $\begin{array}{l}-0.856 \\
(-1.51)\end{array}$ \\
\hline OUT_BLOCK & - & $\begin{array}{l}-0.020 \\
(-0.19)\end{array}$ & $\begin{array}{l}0.023 \\
(0.23)\end{array}$ & $\begin{array}{l}0.034 \\
(0.35)\end{array}$ & $\begin{array}{l}-0.037 \\
(-0.33)\end{array}$ & $\begin{array}{l}-0.071 \\
(-0.57)\end{array}$ \\
\hline DIR_OUT & - & $\begin{array}{l}-0.559^{*} \\
(-1.67)\end{array}$ & $\begin{array}{l}-0.486 \\
(-1.46)\end{array}$ & $\begin{array}{l}-0.563 * \\
(-1.73)\end{array}$ & $\begin{array}{l}-0.588^{*} \\
(-1.68)\end{array}$ & $\begin{array}{l}-0.435 \\
(-1.21)\end{array}$ \\
\hline DIR_APP & + & $\begin{array}{l}0.390 * * \\
(2.05)\end{array}$ & $\begin{array}{l}0.365^{*} \\
(1.90)\end{array}$ & $\begin{array}{l}0.372 * * \\
(2.01)\end{array}$ & $\begin{array}{l}0.396 * * \\
(2.09)\end{array}$ & $\begin{array}{l}0.444 * * \\
(2.13)\end{array}$ \\
\hline CEO_COB & + & $\begin{array}{l}0.086 \\
(0.77)\end{array}$ & $\begin{array}{l}0.050 \\
(0.44)\end{array}$ & $\begin{array}{l}0.077 \\
(0.70)\end{array}$ & $\begin{array}{l}0.121 \\
(1.04)\end{array}$ & $\begin{array}{l}0.121 \\
(0.99)\end{array}$ \\
\hline CONTRACT & + & $\begin{array}{l}0.350^{* * *} \\
(2.81)\end{array}$ & & $\begin{array}{l}0.334^{* * *} \\
(2.75)\end{array}$ & $\begin{array}{l}0.391 \text { *** } \\
(3.00)\end{array}$ & $\begin{array}{l}0.422 * * * \\
(2.97)\end{array}$ \\
\hline GOLD_PAR & - & $\begin{array}{l}-0.103 \\
(-0.76)\end{array}$ & & $\begin{array}{l}-0.104 \\
(-0.80)\end{array}$ & $\begin{array}{l}-0.130 \\
(-0.96)\end{array}$ & $\begin{array}{l}-0.087 \\
(-0.59)\end{array}$ \\
\hline TO_DETER & + & $\begin{array}{l}0.146 \\
(1.25)\end{array}$ & $\begin{array}{r}0.143 \\
(1.22)\end{array}$ & $\begin{array}{r}0.139 \\
(1.23)\end{array}$ & $\begin{array}{l}0.112 \\
(0.91)\end{array}$ & $\begin{array}{l}0.025 \\
(0.19)\end{array}$ \\
\hline CEO_EXP & - & $\begin{array}{l}-0.298 * * * \\
(-3.86)\end{array}$ & $\begin{array}{l}-0.298 * * * \\
(-3.78)\end{array}$ & $\begin{array}{l}-0.282 * * * \\
(-3.74)\end{array}$ & $\begin{array}{l}-0.292 * * * \\
(-3.79)\end{array}$ & $\begin{array}{l}-0.304^{* * *} \\
(-3.85)\end{array}$ \\
\hline ROE & - & $\begin{array}{l}-0.580 * * * \\
(-2.78)\end{array}$ & $\begin{array}{l}-0.697 * * \\
(-3.36)\end{array}$ & $\begin{array}{l}-0.528 * * \\
(-2.59)\end{array}$ & $\begin{array}{l}-0.440 * \\
(-1.94)\end{array}$ & $\begin{array}{l}-0.810^{* * *} \\
(-3.0)\end{array}$ \\
\hline SIZE & + & $\begin{array}{l}0.419^{* * * *} \\
(13.52)\end{array}$ & $\begin{array}{l}0.419^{* * *} \\
(13.26)\end{array}$ & $\begin{array}{l}0.361 \text { *** } \\
(9.61)\end{array}$ & $\begin{array}{l}0.484 * * * \\
(11.36)\end{array}$ & $\begin{array}{l}0.468^{* * *} \\
(11.04)\end{array}$ \\
\hline PRIOR_LIT & + & $\begin{array}{l}0.233^{* *} \\
(2.39)\end{array}$ & $\begin{array}{l}0.245^{* *} \\
(2.47)\end{array}$ & $\begin{array}{l}0.221 \text { ** } \\
(2.33)\end{array}$ & $\begin{array}{l}0.212 * * \\
(2.11)\end{array}$ & $\begin{array}{l}0.283^{* * *} \\
(2.80)\end{array}$ \\
\hline US_OPS & + & $\begin{array}{l}0.285^{* *} \\
(2.62)\end{array}$ & $\begin{array}{l}0.272 * * \\
(2.47)\end{array}$ & $\begin{array}{l}0.229 * * \\
(2.12)\end{array}$ & $\begin{array}{l}0.291 * * \\
(2.60)\end{array}$ & $\begin{array}{l}0.290 * * \\
(2.29)\end{array}$ \\
\hline US_EXCH & + & $\begin{array}{l}0.304^{* * *} \\
(2.92)\end{array}$ & $\begin{array}{l}0.339^{* * *} \\
(3.24)\end{array}$ & $\begin{array}{l}0.233^{* *} \\
(2.22)\end{array}$ & $\begin{array}{l}0.224 * * \\
(2.00)\end{array}$ & $\begin{array}{r}0.200 \\
(1.62)\end{array}$ \\
\hline Residual of $\log$ (limit) & + & $\begin{array}{l}0.439^{* * *} \\
(5.03)\end{array}$ & $\begin{array}{l}0.462^{* * *} \\
(5.24)\end{array}$ & $\begin{array}{l}0.402^{* * *} \\
(4.68)\end{array}$ & $\begin{array}{l}0.502^{* * *} \\
(5.12)\end{array}$ & $\begin{array}{l}0.481 \text { *** } \\
(4.86)\end{array}$ \\
\hline $\log ($ corporate deductible) & $?$ & & & $\begin{array}{l}0.133^{* *} \\
(2.55)\end{array}$ & & \\
\hline Stock Volatility & + & & & & $\begin{array}{l}0.438 \\
(1.62)\end{array}$ & \\
\hline $\begin{array}{l}\text { Industry Effects } \\
\text { Adjusted-R }{ }^{2}\end{array}$ & & $\begin{array}{r}\mathrm{NO} \\
76.3 \%\end{array}$ & $\begin{array}{r}\mathrm{NO} \\
75.3 \%\end{array}$ & $\begin{array}{r}\mathrm{NO} \\
77.6 \%\end{array}$ & $\begin{array}{l}\text { High- } \\
\text { Risk }^{35} \\
77.0 \%\end{array}$ & $\begin{array}{l}\text { All } \\
76.7 \%\end{array}$ \\
\hline \multicolumn{2}{|c|}{$\begin{array}{l}\text { F-test for the restriction that the coefficients on } \\
\text { all of the governance structure variables are } 0\end{array}$} & $2.55 * *$ & $1.86^{*}$ & $2.35^{* *}$ & $2.67 * * *$ & $2.56^{* *}$ \\
\hline $\begin{array}{l}\text { F-test for the restriction th } \\
\text { all of the governance str } \\
\text { for CONTRACT and GC }\end{array}$ & $\begin{array}{l}\text { S on } \\
\text { xcept }\end{array}$ & $2.39 * *$ & $1.86^{*}$ & $2.20 * *$ & $2.48 * *$ & $2.29 * *$ \\
\hline
\end{tabular}


Table 3. Regressions of the logarithm of the D\&O premium and the logarithm of the limit

Panel 1 illustrates the total effect of the variable on $\log$ (premium), which is the sum of the direct effect of the variable on $\log$ (premium) shown in Panel 2 and its indirect effect on $\log$ (premium) through its effect on $\log ($ limit) shown in Panel 3. The sample consists of 110 observations. GOVERNANCE QUALITY is the linear composite of the governance structure variables defined by equation (8), and is standardized to mean zero and unit variance. The residual of $\log (\operatorname{limit})$ is the residual from the regression of $\log$ (limit) shown in Panel 3. All other variables are defined in Table 1. T-statistics (based on OLS standard errors) appear in parentheses below each coefficient estimate.

\begin{tabular}{|c|c|c|c|c|}
\hline \multirow[b]{2}{*}{$\begin{array}{c}\text { Independent } \\
\text { Variable }\end{array}$} & \multirow[b]{2}{*}{$\begin{array}{l}\text { Predicted } \\
\text { Sign }\end{array}$} & \multicolumn{3}{|c|}{ Dependent Variable } \\
\hline & & $\begin{array}{c}\log \\
\text { (premium) } \\
(1)\end{array}$ & $\begin{array}{c}\log \\
\text { (premium) } \\
(2)\end{array}$ & $\begin{array}{c}\log \\
\text { (limit) } \\
(3)\end{array}$ \\
\hline GOVERNANCE QUALITY & - & $\begin{array}{l}-0.275 * * * \\
(-4.92)\end{array}$ & $\begin{array}{l}-0.210 * * * \\
(-3.65)\end{array}$ & $\begin{array}{l}-0.167 * * \\
(-2.42)\end{array}$ \\
\hline CEO_EXP & - & $\begin{array}{l}-0.298 * * * \\
(-5.09)\end{array}$ & $\begin{array}{l}-0.215^{* * *} \\
(-3.53)\end{array}$ & $\begin{array}{l}-0.212 * * * \\
(-2.93)\end{array}$ \\
\hline ROE & - & $\begin{array}{l}-0.580 * * * \\
(-2.96)\end{array}$ & $\begin{array}{l}-0.473 * * \\
(-2.40)\end{array}$ & $\begin{array}{l}-0.275 \\
(-1.13)\end{array}$ \\
\hline SIZE & + & $\begin{array}{l}0.419^{* * *} \\
(15.66)\end{array}$ & $\begin{array}{l}0.323 * * * \\
(9.69)\end{array}$ & $\begin{array}{l}0.248 * * * \\
(7.49)\end{array}$ \\
\hline PRIOR_LIT & + & $\begin{array}{l}0.233 * * \\
(2.50)\end{array}$ & $\begin{array}{l}0.207^{* *} \\
(2.22)\end{array}$ & $\begin{array}{l}0.068 \\
(0.59)\end{array}$ \\
\hline US_OPS & + & $\begin{array}{l}0.285 * * * \\
(2.75)\end{array}$ & $\begin{array}{l}0.190^{*} \\
(1.81)\end{array}$ & $\begin{array}{l}0.244^{*} \\
(1.91)\end{array}$ \\
\hline US_EXCH & + & $\begin{array}{l}0.304 * * * \\
(3.09)\end{array}$ & $\begin{array}{l}0.138 \\
(1.33)\end{array}$ & $\begin{array}{l}0.426^{* * *} \\
(3.51)\end{array}$ \\
\hline $\log ($ limit $)$ & + & & $\begin{array}{l}0.388^{* * * *} \\
(4.85)\end{array}$ & \\
\hline $\begin{array}{l}\text { Residual } \log (\text { limit }) \\
\text { from Panel } 3\end{array}$ & + & $\begin{array}{l}0.388 * * * \\
(4.85)\end{array}$ & & \\
\hline Adjusted- $\mathrm{R}^{2}$ & & $77.5 \%$ & $77.5 \%$ & $45.1 \%$ \\
\hline $\mathrm{F}$ & & $47.87 * * *$ & $47.87 * * *$ & $13.78 * * *$ \\
\hline
\end{tabular}

$* * *, * *, *$ significant at the $0.01,0.05,0.10$ level (two-tail). 
Table 4. Descriptive Statistics for CEO Compensation and its Hypothesized Determinants

The sample consists of 208 observations. With the exception of RETURN and ROE, which are measured in the fiscal year during which CEO compensation is earned, all other variables are measured at the end of the fiscal year or for the fiscal year ending prior to the year during which CEO compensation is earned. Dollar amounts are in Canadian dollars.

CEO Compensation

\begin{tabular}{llrrr}
\hline Variable & Variable Definition & Mean & Median & Std Dev \\
\hline Total compensation & $\begin{array}{l}\text { Total of: (1) base salary; (2) annual } \\
\text { incentive payments; (3) the estimated value } \\
\text { of option grants and grants under long-term } \\
\text { incentive plans; plus (4) the cash value of } \\
\text { any benefits and perquisites. }\end{array}$ & $1,086,739$ & 656,916 & $1,283,698$ \\
$\begin{array}{l}\text { Logarithm of total compensation } \\
\text { log(Total } \\
\text { compensation) }\end{array}$ & & & & \\
\end{tabular}

Explanatory Variables

\begin{tabular}{|c|c|c|c|c|c|}
\hline Variable & Variable Definition & $\begin{array}{l}\text { Predicted } \\
\text { Sign }\end{array}$ & Mean & Median & Std Dev \\
\hline $\begin{array}{l}\text { GOVERNANCE } \\
\text { QUALITY }\end{array}$ & $\begin{array}{l}\text { Standardized linear composite of the } \\
\text { governance structure quality variables } \\
\text { defined by equation }(8)\end{array}$ & - & 0.000 & 0.028 & 1.000 \\
\hline SIZE & Logarithm of total assets & + & 20.521 & 20.462 & 1.749 \\
\hline GROWTH_OPP & $\begin{array}{l}\text { Market value of the firm's equity plus the } \\
\text { book value of the firm's liabilities, divided } \\
\text { by total assets }\end{array}$ & + & 1.406 & 1.117 & 0.934 \\
\hline RETURN & Percentage annual stock return & + & $52.6 \%$ & $33.1 \%$ & $79.0 \%$ \\
\hline ROE & $\begin{array}{l}\text { Net income before extraordinary items } \\
\text { divided by ending equity }\end{array}$ & + & $-3.6 \%$ & $5.8 \%$ & $40.2 \%$ \\
\hline US EXCH & $=1$ if the firm is listed on a U. S. exchange & + & 0.298 & 0.000 & 0.459 \\
\hline US OPS & $=1$ if the firm has sales or assets in the U.S. & + & 0.697 & 1.000 & 0.461 \\
\hline
\end{tabular}


Table 5. Regressions of the logarithm of CEO compensation

Core 37

GOVERNANCE QUALITY is the linear composite of the governance structure variables defined by equation (8), and is standardized to mean zero and unit variance. (GOVERNANCE QUALITY) X (firm has insurance) is an interactive variable equal to GOVERNANCE QUALITY if the firm has D\&O insurance, and 0 otherwise. PREMIUM RESIDUAL is the residual from the regression equation (9), which excludes the governance structure variables. PREMIUM RESIDUAL is standardized to mean zero and unit variance. Other variables are defined in Table 4. T-statistics (based on OLS standard errors) appear in parentheses below each coefficient estimate.

\begin{tabular}{|c|c|c|c|c|}
\hline $\begin{array}{l}\text { Independent } \\
\text { Variable }\end{array}$ & $\begin{array}{l}\text { Predicted } \\
\text { Sign }\end{array}$ & (1) & (2) & (3) \\
\hline GOVERNANCE QUALITY & - & $\begin{array}{l}-0.231 * * * \\
(-4.80)\end{array}$ & $\begin{array}{l}-0.152 * \\
(-1.87)\end{array}$ & \\
\hline $\begin{array}{l}\text { (GOVERNANCE QUALITY) X } \\
\text { (firm has insurance) }\end{array}$ & ? & & $\begin{array}{l}-0.123 \\
(-1.22)\end{array}$ & \\
\hline PREMIUM RESIDUAL & + & & & $\begin{array}{l}0.127^{*} \\
(1.75)\end{array}$ \\
\hline SIZE & + & $\begin{array}{l}0.253^{* * *} \\
(8.29)\end{array}$ & $\begin{array}{l}0.248 * * * \\
(8.08)\end{array}$ & $\begin{array}{l}0.211 * * * \\
(4.48)\end{array}$ \\
\hline GROWTH_OPP & + & $\begin{array}{l}0.102 * \\
(1.84)\end{array}$ & $\begin{array}{l}0.110^{*} \\
(1.97)\end{array}$ & $\begin{array}{l}0.264^{* * *} \\
(2.86)\end{array}$ \\
\hline RETURN & + & $\begin{array}{l}0.190^{* * *} \\
(3.01)\end{array}$ & $\begin{array}{l}0.192 * * * \\
(3.02)\end{array}$ & $\begin{array}{r}0.122 \\
(1.53)\end{array}$ \\
\hline ROE & + & $\begin{array}{r}0.078 \\
(0.66)\end{array}$ & $\begin{array}{r}0.097 \\
(0.81)\end{array}$ & $\begin{array}{r}0.084 \\
(0.58)\end{array}$ \\
\hline US_EXCH & + & $\begin{array}{l}0.202 * \\
(1.88)\end{array}$ & $\begin{array}{l}0.212 * \\
(1.97)\end{array}$ & $\begin{array}{r}0.010 \\
(0.06)\end{array}$ \\
\hline US_OPS & + & $\begin{array}{l}-0.074 \\
(-0.69)\end{array}$ & $\begin{array}{l}-0.064 \\
(-0.59)\end{array}$ & $\begin{array}{l}-0.117 \\
(-0.67)\end{array}$ \\
\hline $\operatorname{adj}-R^{2}$ & & $30.2 \%$ & $29.5 \%$ & $18.7 \%$ \\
\hline $\mathrm{F}$ & & $13.78 * * *$ & $11.77 * * *$ & $4.16^{* * *}$ \\
\hline Sample Size & & 208 & $207^{36}$ & 97 \\
\hline
\end{tabular}

$* * *, * *, *$ significant at the $0.01,0.05,0.10$ level (two-tail). 


\section{Endnotes}

${ }^{1}$ This definition blends more traditional definitions of corporate governance quality (from the perspective of minimizing agency costs to outside shareholders) employed by, for example, Shleifer and Vishny (1997) with the definition of governance as a set of constraints defined broadly by Zingales (1998) and operationalized in the case of shareholders and managers by Nelson (1999). Note that my definition does not necessarily imply that weak governance is bad for shareholders. As a counterexample, shareholders may maximize share value by giving a talented manager loose constraints, and then suing when that manager makes bad choices.

${ }^{2}$ Overall, the legal systems in the two countries are quite similar in their legal protection of investors (La Porta, Lopes-de-Silanes, Shleifer, and Vishny, 1997) and in regard to D\&O claims (Daniels and Hutton, 1993).

Historically, the Canadian system is less expensive and less conducive to nuisance suits because in Canada, tort cases are typically settled by a judge alone; the contingent fee system is used less frequently and contingency fees are subject to a reasonableness standard; the loser pays part of the winner's legal expenses; punitive damages are rarely granted; and class actions and derivative actions are less frequent (Trebilcock,1987; Daniels and Hutton, 1993; Clarkson and Simunic, 1994).

However, Canadian legal practices have a tendency to converge toward U.S. practices (Baillie, 1996). Particular areas of such convergence of include: (1) changes beginning in 1992 expanding class action litigation; (2) the requirement in 1993 of U.S.- 
style proxy disclosure of executive pay; (3) the requirement in 1995 that firms disclose their compliance with a set of governance principles (Rousseau, 1997); and (4) consideration to increase $\mathrm{D} \& \mathrm{O}$ liability for inadequate or misleading disclosure (Rowley, 1996).

${ }^{3}$ Source: The Wyatt Company, 1993 Directors and Officers Liability Survey (U.S. participants only) and 1989 Wyatt Canadian Directors and Officers Liability Survey (cited in Daniels and Hutton, 1993, p. 190). The Wyatt Company conducts an annual survey of D\&O claims in the U.S., and is recognized as the sole public source of information on this insurance. The Wyatt Company discontinued its Canadian survey in 1991.

${ }^{4}$ Although corporate law in Canada and in the U.S. permits firms to indemnify their directors and officers against most claims, certain claims by law may not be indemnified (e.g., shareholder derivative suits in which shareholders sue D\&Os on behalf of the firm). In addition, the firm may be unable to provide indemnification because of financial distress, and new managers may be unwilling to indemnify old managers following a change-in-control. Parry and Parry (1991) suggest that a principal purpose of D\&O insurance is to protect officers and directors when indemnification is not available. ${ }^{5}$ For example, suppose a firm carries a policy with an annual limit of $\$ 15$ million. In the event that two groups of D\&Os were each to suffer $\$ 10$ million in covered losses in the policy year, the first group of D\&Os to make a claim would receive $\$ 10$ million in 
reimbursement (less any deductible) and the second group would receive the remainder of the limit, $\$ 5$ million, for the second claim.

${ }^{6}$ An exception to the symmetric information assumption occurs in the unusual circumstance when one of the D\&Os intentionally misrepresents a known risk of suit on the policy application or policy renewal form. Canadian law permits the insurer to revoke the policy entirely under such a circumstance. In contrast, U.S. law allows the insurer to deny coverage to the $\mathrm{D} \& \mathrm{O}(\mathrm{s})$ who intentionally lied, but requires that the insurer provide coverage to the innocent $\mathrm{D} \&$ Os. These differences in law suggest another reason that litigation risk will be higher for firms with U.S. exchange listings. The inclusion of fraudulent financial statements in the policy application or renewal form is the most frequent example of an intentional misrepresentation. Given previously-documented links between financial statement fraud and weak governance (e.g. Dechow, Sloan, and Sweeney, 1996), the hypothesized increase in the premium related to weak governance may also reflect the insurer's assessment of an increased probability of the firm's withholding adverse information when it has weaker governance.

${ }^{7}$ If firms' governance structures are continuously optimized, governance structure and business risk are jointly determined functions of a small number of firm-specific variables (e.g., Demsetz, 1983; Fama and Jensen, 1983; and Smith and Watts, 1992). However, recent evidence suggests that transactions costs allow sub-optimal governance structures to persist (e.g., Shleifer and Vishny, 1997). The D\&O premium regressions test whether there is information in the governance structure variables incremental to the business risk 
control variables, and whether the coefficients on the governance structure variables are consistent with the interpretation that weaker governance increases litigation risk. ${ }^{8}$ At least ten insurers were underwriting primary coverage for Canadian-only risks, but a large Canadian firm could purchase D\&O insurance from another thirty to forty firms underwriting in the U.S. and worldwide (Source: interviews with a Canadian D\&O broker and a Canadian D\&O underwriter).

${ }^{9}$ See Cummins (1991) for a discussion of symmetric information insurance contracting and D'Arcy et al. (1990) for a discussion of insurance ratemating.

${ }^{10}$ The use of $\log ($ limit) as a proxy for the expected loss omits information in the deductible that may affect the premium. Sensitivity analysis described in Section 4.2 indicates that the results are unaffected by the omission of the deductible. In addition, I obtain qualitatively the same results if I use a first-stage factor-analytic method that forms a proxy for the logarithm of the expected loss as a weighted sum of the logarithms of the limit and deductible, their squares, and their cross-product (a translog approximation). 11 The cost-minimizing choice of the limit involves a trade-off of the marginal cost of the extra limit (charged by the risk-neutral insurer) versus the marginal benefit of reducing the risk-averse D\&O's risk-premium. Because it is not possible for an individual director to buy coverage (Parry and Parry, 1991; interviews with D\&O underwriters), it is cheaper for the firm to buy insurance rather than to increase the D\&O's compensation. The D\&O's risk-premium increases with litigation risk faster than the insurance premium (Holderness, 1990). Therefore, the net benefits of purchasing a higher limit increase in 
the firm's litigation risk, and it is not necessary to control for the marginal cost of the insurance.

12 This assumption appears to be contradicted by Holderness (1990), who states that "sometimes the issuance of a policy is predicated on specific organizational changes" ( $p$. 119). However, Holderness was describing the non-competitive market of the D\&O crisis years of the late 1980s, when severe capacity constraints gave insurers the market power to act as oligopolists. When the $\mathrm{D} \& \mathrm{O}$ market is competitive (as it was during the sample period), policies are readily available from a number of insurers, premiums are relatively low, and firm managers prefer to pay for the extra risk rather than make a costly change to governance.

13 This sample was obtained by mailing a request (and follow-up request) for proxy statements and annual reports to each of the 375 publicly-traded Canadian companies listed on the Compact Disclosure Worldscope.

${ }^{14}$ Some firms disclosed only the premium paid for the corporate coverage or the personal coverage portion of their $\mathrm{D} \& \mathrm{O}$ policies. This partial premium is not comparable to a premium paid for both portions of the $\mathrm{D} \& \mathrm{O}$ insurance policy. Firms whose insurance is provided by their parents are dropped because the cost allocation of the premium to the subsidiary is made by the parent, and is arbitrary.

${ }^{15}$ For those firms that report in U.S. dollars, amounts have been converted to Canadian dollars using a monthly series of the spot exchange rate (obtained from the Datastream 
service). To make a rough conversion of Canadian dollars into U.S. dollars, multiply the Canadian dollar figure by 0.8 .

${ }^{16}$ Canadian proxy disclosure only requires ownership information for inside officers who are also directors, in contrast to U.S. disclosure of ownership for both officers and directors.

17 The disclosure threshold for blockholders of a Canadian-listed company is control of $10 \%$ of a class of stock (as compared to $5 \%$ for a U.S. company).

${ }^{18}$ While the governance literature consistently predicts a negative association between governance quality and a dual $\mathrm{CEO} /$ board chair and positive association between governance quality and the proportion of outside directors, the evidence is mixed (e.g., Brickley, Coles, and Jarrell, 1997; Core, Holthausen, and Larcker, 1999).

${ }^{19}$ Consistent with Weisbach (1988), I define outside directors as non-inside, non-gray directors. An inside director is a director who is a manager, retired manager, or relative of a manager. A non-inside director is considered gray if he or his employer receives payments from the firm in excess of his board pay.

${ }^{20}$ Canadian proxy statements provide much less biographical data than U.S. proxy statements. The number of years the CEO has held his position or the number of other boards on which the CEO serves is usually not disclosed, so that it is not possible to create proxies for CEO quality based on these variables.

${ }^{21}$ Part of this information arises because the limits are sold in discrete multiples of five million dollars (typically). Thus, even if the firm's desired limit were completely 
determined by the proxies for litigation risk, because of the discreteness in the actual limit, there will be information in the residual limit that will be associated with the premium.

${ }^{22}$ The total effect is the sum of the variable's direct effect on $\log$ (premium) and its indirect effect on $\log ($ premium$)$ through its effect on the amount of coverage purchased, $\log$ (limit). Section 4.3 illustrates that governance structure quality has a significant direct and indirect effect on $\log ($ premium$)$.

${ }^{23}$ Inference is unaffected if OUT_BLOCK is dropped from the regression.

${ }^{24}$ If the residual of $\log ($ limit) is omitted as an explanatory variable from the reducedform model, the adjusted $\mathrm{R}^{2}$ falls to $70.7 \%$, the coefficients on the remaining variables are the same, but their standard errors increase by approximately $12 \%$. Although significance levels are reduced, a partial F-test rejects the hypothesis that the coefficients on all of the governance structure variables are equal to zero ( $\mathrm{p}$-value $=0.05)$.

${ }^{25}$ Instead of being deleted in the second-stage regression, leveraged outliers, as measured by the DFFITs criterion (Belsley, Kuh, and Welsch, 1980), are downweighted.

${ }^{26}$ A stepwise multivariate logit model indicates that inside voting control is negatively associated with contracts (which is consistent with contracts being a substitute for voting control as an entrenchment device), and that a US exchange listing is positively associated with contracts (which is consistent with contracts proxying for a business risk). In the CEO pay regressions discussed below, contracts are associated with higher CEO pay, which is consistent with an interpretation of entrenchment (e.g., Borokovich, 
Brunarski, and Parrino, 1997), or consistent with the contracts proxying for an omitted determinant of CEO pay (e.g., CEO quality if the Smith and Watts (1992) proxies do not entirely capture the firm's demand for a high-quality CEO).

${ }^{27}$ To test this hypothesis, I estimate a regression model in which there are different coefficients on each the governance structure variables (other than INS_VOTE) for the multiple class firms and for the single class firms. An F-test does not reject the restriction that the coefficients are equal on each the governance structure variables, providing no evidence of differing effects for the two groups of firms.

${ }^{28}$ Because $\log$ (limit) is a function of the both the firm's governance structure and business risk, the regressions in Panels 1 and 2 have the same adjusted- $\mathrm{R}^{2}$, and $\log$ (limit) and residual of $\log ($ limit) have identical coefficients.

${ }^{29}$ A Towers Perrin study quoted by Beauchesne (1994) indicates that a CEO of a Canadian firm with U.S. $\$ 250 \mathrm{~mm}$ in sales earned U.S. $\$ 404,000$ while a CEO of the same-sized U.S. company earned U.S.\$777,000.

${ }^{30}$ Canadian firms with fiscal years ending before October 31, 1993 were not required to disclose disaggregated compensation data for individual executives, and for this reason CEO compensation data was missing for 27 firms.

${ }^{31}$ Stock options are valued with a 200-node Cox-Ross-Rubinstein (1979) binomial model that values the impact of optimal early exercise. Long-term incentive grants are valued assuming target performance is achieved. 
${ }^{32}$ The inference from Table 5 is not affected if CONTRACT and GOLD_PAR are excluded from the measure GOVERNANCE QUALITY.

${ }^{33}$ Recall that, by construction, the residuals in equations (4) and (7) are the same.

${ }^{34}$ The results for CEO compensation presented in Table 5 are robust to alternative specifications. Inference is unchanged if twelve industry dummy variables are included in the regressions or if $\log$ (cash compensation) is used instead to proxy for CEO compensation. Inference is also unchanged if leveraged outliers are downweighted using the Welsch (1980) procedure described above.

35 The high-risk industries are technology, media, banking, other financial institutions, and real estate. All industries includes another seven dummy variables for the remaining industry groups.

${ }^{36}$ Excluded from this regression is one firm which stated the intention to purchase D\&O insurance, but disclosed no coverage, as it is unclear whether this firm should be classified as having insurance or not. 